\title{
Honokiol: a promising small molecular weight natural agent for the growth inhibition of oral squamous cell carcinoma cells
}

\author{
Xi-rui Chen ${ }^{1}$, Rui $\mathrm{Lu}^{2}$, Hong-xia $\mathrm{Dan}^{2}$, Ga Liao ${ }^{2}$, Min $\mathrm{Zhou}^{2}$, Xiao-yu Li ${ }^{2}, \mathrm{Ning} \mathrm{Ji}^{2}$ * \\ ${ }^{1}$ Pharmacology and Toxicology Program, Faculty of Art and Science, University of Toronto, Ontario, Canada; ${ }^{2}$ State \\ Key Laboratory of Oral Diseases, West China School of Stomatology, Sichuan University, Chengdu 610041, China
}

Honokiol (HNK) is a small organic molecule purified from magnolia species and has demonstrated anticancer activities in a variety of cancer cell lines; however, its effect on oral squamous cell carcinoma (OSCC) cells is unknown. We investigated the antitumor activities of HNK on OSCC cells in vitro for the first time. The inhibitory effects of HNK on the growth and proliferation of OSCC cells were demonstrated via in vitro 3-(4,5-dimethyl thiazol-2-yl)-2,5-diphenyltetrazolium bromide (MTT) and propidium iodide (PI) assays, and the apoptotic cells were investigated by the observation of morphological changes and detection of DNA fragmentation via PI, TdT-mediated dUTP-biotin nick end labeling (TUNEL), and DNA ladder assays, as well as flow cytometry assay. The results showed that HNK inhibited the growth and proliferation of OSCC cells in vitro in a time and dose-dependent manner. The inhibitory effect was associated with the cell apoptosis induced by HNK, evidenced by the morphological features of apoptotic cells, TUNEL-positive cells and a degradation of chromosomal DNA into small internucleosomal fragments. The study also demonstrated here that the inhibition or apoptosis mediated by $15 \mu \mathrm{g} \cdot \mathrm{mL}^{-1}$ or $20 \mu \mathrm{g} \cdot \mathrm{mL}^{-1}$ of $\mathrm{HNK}$ were more stronger compared with those of $20 \mu \mathrm{g} \cdot \mathrm{mL}^{-1}$ 5-fluorouracil (5-Fu, the control) applied to OSCC cells, when the ratio of OSCC cell numbers were measured between the treatment of different concentrations of HNK to the 5-Fu treatment for $48 \mathrm{~h}$. HNK is a promising compound that can be potentially used as a novel treatment agent for human OSCC.

Keywords: honokiol; oral squamous cell carcinoma; anticancer; apoptosis

International Journal of Oral Science (2011) 3: 34-42. doi: 10.4248/IJOS11014

\section{Introduction}

Carcinomas of the oral cavity, especially oral squamous cell carcinoma (OSCC), are one of the most leading causes that related to death worldwide. Data from the International Agency for Research on Cancer (IARC) show that there are more than 200000 new cases of OSCC each year worldwide. The five-year and ten-year

\footnotetext{
*Correspondence: Ning Ji

Tel: 13730804363; E-mail: jiningcoming@sohu.com

Received 2 July 2010; Accepted 19 October 2010
}

relative survival rates are $59 \%$ and $48 \%$, respectively [1]. Currently, surgery, radiation and chemotherapy are three major modalities applied in the conventional treatment of this malignant disorder [2]. Chemotherapy (pre- or post-surgery) is beneficial for local control and survival improvement, although it does not always induce a substantially positive response [3]. In fact, the lack of effective chemotherapeutic drug results in a high death rate in patients with OSCC [4]. Therefore, effective chemotherapy medicines for OSCC are highly desirable and demanded.

Honokiol (HNK) is a small organic molecule purified 
from magnolia species. Evidence has demonstrated that HNK has a variety of pharmacological effects, such as anti-inflammatory [4], antithrombotic [5], anti-arrhythmic [4], antioxidative [6] and anxiolytic [7]. Indeed, it has been reported that HNK could inhibit cell proliferation and induce cytotoxicity in a variety of cell lines derived from cancers such as prostate, blood vessel, blood, lung, colon, liver, etc. [8-13]. However, little is known about the antitumor effects of HNK on OSCC. Therefore, in this study we chose OSCC cell lines to investigate its possible function on OSCC cell lines in vitro and explore the possible mechanism for its inhibitory effects, trying to lay the basis for the potential application in the clinical practice of OSCC treatment.

\section{Materials and Methods}

\section{Cell line and Reagents}

Two oral sqamous cell carcinoma cell lines, HSC-3 and HSC-4, were purchased from Japanese Collection of Research Bioresources (JCRB) Cell Bank, and maintained in DMEM medium (Gibco, USA) supplemented with $10 \%$ heat inactivated fetal bovine serum (APP, Italian) at $37{ }^{\circ} \mathrm{C}$ in $5 \% \mathrm{CO}_{2} . \mathrm{HNK}$ was purchased from Sikehua Biotechnology Co. (Chengdu, China), and dissolved in dimethyl sulfoxide (DMSO) at the stock concentration of $20 \mathrm{~g} \cdot \mathrm{L}^{-1}$. The latter was further diluted in culture medium at the final DMSO concentration $<0.1 \%$ and the HNK maximum concentration of $20 \mu \mathrm{g} \cdot \mathrm{mL}^{-1}$. 5-fluorouracil (5-Fu) was purchased from China National Pharmaceutical Group Co. (Shanghai, China), dissolved in $\mathrm{ddH}_{2} \mathrm{O}$ at the stock concentration of $10 \mathrm{~g} \cdot \mathrm{L}^{-1}$.

\section{3-(4,5-dimethylthiazol-2-yl)-2,5-diphenyltetrazolium bro- mide assay}

Cell growth and viability were assessed by 3-(4, 5dimethylthiazol-2-yl)-2, 5-diphenyltetrazolium bromide (MTT) assay. The kit was purchased from Sigma Chemical Corporation, USA. In brief, the cells $\left(1 \times 10^{4}\right.$ in $100 \mu \mathrm{L})$ were seeded on 96-well plates in triplicate. Following a culture at $37{ }^{\circ} \mathrm{C}$ for $24 \mathrm{~h}$, the medium was replaced with fresh medium at various concentrations of HNK $\left(10,15\right.$ or $20 \mu \mathrm{g} \cdot \mathrm{mL}^{-1}$, individually) or $20 \mu \mathrm{g} \cdot \mathrm{mL}^{-1}$ $5-\mathrm{Fu}$ (the control) in total volume of $200 \mu \mathrm{L}$. Then, cells were incubated further at $37^{\circ} \mathrm{C}$ for $12,24,48$ or $72 \mathrm{~h}$, individually. Finally, $20 \mu \mathrm{L}$ of MTT [ $5 \mathrm{mg} \cdot \mathrm{mL}^{-1}$ in phosphate buffer saline (PBS)] was added to each well, and the cells were incubated for an addition of $4 \mathrm{~h}$, and then the media were removed. MTT formazan precipitate was dissolved in $150 \mu \mathrm{L}$ of DMSO, shaken mechanically for $30 \mathrm{~min}$ and then read immediately at $570 \mathrm{~nm}$ in a plate reader (Microplate Reader VersaMax, Molecular Devices
Co., USA) [14].

\section{Propidium iodide assay}

Cells $\left(3 \times 10^{5}\right.$ in $\left.2 \mathrm{~mL}\right)$ were seeded on six-well plates. Following a $24 \mathrm{~h}$-culture at $37^{\circ} \mathrm{C}$, the media were replaced with fresh medium at various concentrations of $\mathrm{HNK}\left(10,15\right.$ or $20 \mu \mathrm{g} \cdot \mathrm{mL}^{-1}$, individually), or $20 \mu \mathrm{g} \cdot \mathrm{mL}^{-1}$ $5-\mathrm{Fu}$ (the control) in a final volume of $2 \mathrm{~mL}$. Cells were further incubated at $37{ }^{\circ} \mathrm{C}$ for $48 \mathrm{~h}$. After the treatment, cells were washed with PBS and fixed by $4 \%$ methanolfree formaldehyde solution in PBS at $4{ }^{\circ} \mathrm{C}$ for $25 \mathrm{~min}$, then washed with $\mathrm{PBS}$. $50 \mu \mathrm{L}$ propidium iodide $(\mathrm{PI}$, $50 \mu \mathrm{g} \cdot \mathrm{mL}^{-1}$ ) was added to the plate and finally the cells were visualized under fluorescence reverse microscope (Leica DMI 6000B, Leica Co., Germany) [15].

\section{TUNEL assay}

The DeadEnd ${ }^{\mathrm{TM}}$ Fluorometric TUNEL (TdT-mediated dUTP-biotin nick end labeling) system (Promega Inc., USA) was used. In brief, cells $\left(3 \times 10^{5}\right.$ in $\left.2 \mathrm{~mL}\right)$ were seeded on six-well plates. Following a $24 \mathrm{~h}$-culture at $37{ }^{\circ} \mathrm{C}$, the medium was replaced with fresh medium at $15 \mu \mathrm{g} \cdot \mathrm{mL}^{-1}$ of $\mathrm{HNK}$ in a final volume of $2 \mathrm{~mL}$. Cells were further incubated at $37{ }^{\circ} \mathrm{C}$ for $48 \mathrm{~h}$, and washed with PBS and fixed by $4 \%$ methanol-free formaldehyde solution in PBS at $4{ }^{\circ} \mathrm{C}$ for $25 \mathrm{~min}$, and then further washed with PBS and permeablized by $0.2 \%$ Triton X-100 in PBS for $5 \mathrm{~min}$ at room temperature. Finally the staining was carried out according to the manufacturer's instructions and fluorescence was visualized to count TUNEL-positive cells with Leica DMI 6000B microscope (Leica DMI 6000B, Leica Co., Germany) [16].

\section{DNA ladder assay}

To detect DNA fragments, OSCC cells were exposed to $15 \mu \mathrm{g} \cdot \mathrm{mL}^{-1} \mathrm{HNK}$ for $48 \mathrm{~h}$, then collected and lysed with lysis buffer, containing $50 \mathrm{mmol} \cdot \mathrm{L}^{-1}$ Tris- $\mathrm{HCl}(\mathrm{pH}$ 7.5), $20 \mathrm{mmol} \cdot \mathrm{L}^{-1}$ ethylenediamine tetraacetic acid, and $10 \mathrm{~g} \cdot \mathrm{L}^{-1} \mathrm{NP}-40$. Then $10 \mathrm{~g} \cdot \mathrm{L}^{-1}$ SDS and RNase $\left(5 \mu \mathrm{g} \cdot \mathrm{mL}^{-1}\right)$ were added, incubated at $56{ }^{\circ} \mathrm{C}$ for $2 \mathrm{~h}$, followed by incubation with proteinase $\mathrm{K}\left(2.5 \mu \mathrm{g} \cdot \mathrm{mL}^{-1}\right)$ at $37^{\circ} \mathrm{C}$ for $2 \mathrm{~h}$. Finally, the DNA was precipitated by addition of both ammonium acetate $\left(3.3 \mathrm{~mol} \cdot \mathrm{L}^{-1}\right)$ and ethanol $(99.5 \%)$, dissolved in a loading buffer (Takara, Japan), and illustrated the DNA fragmentation under ultraviolet light (Bio-Rad, American) [17] after the electrophoresis on $2 \%$ agarose gels (Gene-Tech Co., Shanghai, China).

\section{Flow cytometry assay}

Apoptotic rates of the cells were analyzed by flow cytometry (FCM) using Annexin V-FITC/PI Apoptosis 
Detection Kit (R \& D systems, Abingdon, United Kingdom) according to the manufacturer's instructions. In brief, flow cytometry assay was performed on a FACSAria flow cytometry system (BD Biosciences). Data were analyzed by using BD FACSDiva software, and presented as dot plots showing fluorescence intensity of Annexin- $\mathrm{V}$ fluorescein isothiocyanate (Annexin-V FITC) and PI [18].

\section{Statistical analysis}

Values were given as mean $\pm \mathrm{SD}$. Statistical comparisons were made by Student's $t$-test, and $P<0.05$ was taken as the significance.

\section{Results}

\section{HNK inhibited the OSCC cell growth}

MTT assays were carried out to evaluate the cell viability upon treatment with three different concentrations of $\mathrm{HNK}\left(10,15\right.$ or $20 \mu \mathrm{g} \cdot \mathrm{mL}^{-1}$, individually), or $20 \mu \mathrm{g} \cdot \mathrm{mL}^{-1} 5-\mathrm{Fu}$ (the control), which are based on our pilot studies (Data not shown) and previous report [17]. A pronounced increase in growth inhibition occurred after the treatment with those agents (Figures 1,2), although the low dosage $\left(10 \mu \mathrm{g} \cdot \mathrm{mL}^{-1}\right)$ group of $\mathrm{HNK}$ also tended to slightly enhancing growth at the early stage in an unknown reason. Those phenomena demonstrated the ability in inhibitory efficiency of HNK on OSCC cells. The positive control $\left(20 \mu \mathrm{g} \cdot \mathrm{mL}^{-1} 5-\mathrm{Fu}\right)$ demonstrated the same results, confirmed the inhibition effects.

To further confirm our observations, a PI assay was performed to visualize the survival OSCC cells and to evaluate cancer cell killing efficiency in those treatment via HNK or 5-Fu. Consistent with data in MTT assay, these agents resulted in a marked decrease in the number of cells with statistic significance $(P<0.01)$ (Figures 1, 2).

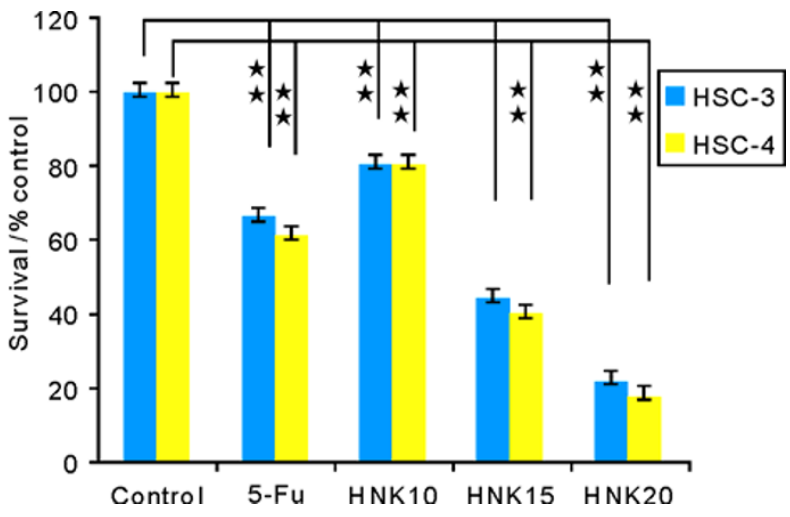

Figure 1 Dose-dependent inhibition effects of OSCC cells exposed to HNK or 5-Fu shown by MTT assay. HSC-3 or HSC-4 cells were treated as the described in Materials and Methods, and the MTT values were detected after $48 \mathrm{~h}$. The values indicated a significant decrease $(P<0.01)$ in cell proliferation when the cells were treated with $20 \mu \mathrm{g} \cdot \mathrm{mL}^{-1} 5$-Fu or treated with three variety of concentrations of HNK. The results also demonstrated that the cytotoxicity increased remarkably with the increase of the concentration of HNK. All experiments were performed in triplicate and the results were expressed as the mean $\pm S D$ of the measurements of three experiment. Asterisk $(\star \star)$ indicated the significance $P<0.01$.
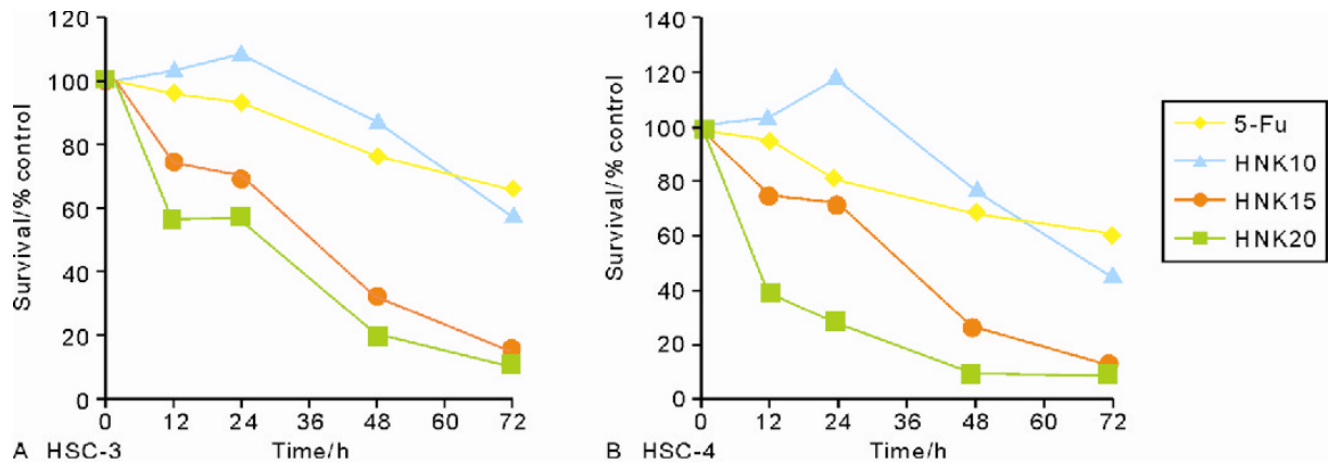

Figure 2 Time-dependent inhibition of OSCC cells exposed to HNK shown by MTT assay. HSC-3 or HSC-4 cells were treated as the described in Materials and Methods, and the MTT values were detected at different time points. After $24 \mathrm{~h}$, the effect of inhibition of OSCC cells proliferation was increased obviously, and the treatment of OSCC cells with $20 \mu \mathrm{g} \cdot \mathrm{mL}^{-1}$ of $5-\mathrm{Fu}, 15 \mu \mathrm{g} \cdot \mathrm{mL}^{-1}$ or $20 \mu \mathrm{g} \cdot \mathrm{mL}^{-1}$ of $\mathrm{HNK}$ resulted in a sharply growth inhibition at various time points. Moreover, the effect of growth inhibition mediated by three concentrations of HNK were more prolonged compared with that of $20 \mu \mathrm{g} \cdot \mathrm{mL}^{-1} 5-\mathrm{Fu}$ in OSCC cells after $72 \mathrm{~h}$. All experiments were performed in triplicate and the results were expressed as the mean $\pm S D$ of the measurements of three experiments. 
The inhibitory effects of HNK on OSCC cells showed a time and dosage dependent manner

The MTT values were detected from $0 \mathrm{~h}$ to $72 \mathrm{~h}$ with $12 \mathrm{~h}$ or $24 \mathrm{~h}$ interval at different time points to test whether the inhibitory effect of HNK on OSCC cells was in a time (Figure 2) dependent manner, and the results demonstrated that the inhibitory effects of cell proliferation were obvious after the exposure of cells to HNK in both cell lines, and the increase in killing efficiency significantly concurred with the time course, although the value was a slight tendency of the cell number to go up at the lower dosage of $\mathrm{HNK}\left(10 \mu \mathrm{g} \cdot \mathrm{mL}^{-1}\right)$ at the early treatment stage (before $24 \mathrm{~h}$ ).

The MTT assays were also performed to evaluate whether the inhibitory effect of HNK to concur with the dosage increase at three different concentrations of 10 , 15 or $20 \mu \mathrm{g} \cdot \mathrm{mL}^{-1}$, respectively. The results were shown in
Figure 1 and demonstrated that HNK-mediated cytotoxicity enhanced remarkably with the increase of the concentration of $\mathrm{HNK}$, indicating a dosage-dependent manner. Indeed, posterior to the $48 \mathrm{~h}$ treatment, the cell number decreased by about $60 \%$ in the $15 \mu \mathrm{g} \cdot \mathrm{mL}^{-1}$ or $80 \%$ in the $20 \mu \mathrm{g} \cdot \mathrm{mL}^{-1} \mathrm{HNK}$ group in both cell lines (Figures 1,2) when compared with that of the untreated cells.

Moreover, another assay (PI assay) was performed to detect of the proliferation inhibition of OSCC cells. Consistent with the data from the above MTT assay, HNK-mediated cytotoxicity grew up dramatically with the increase of the concentration of HNK. A significant decrease $(P<0.01)$ in cell number was observed at the cells treated with three concentrations of HNK for $48 \mathrm{~h}$ (Figure 3).
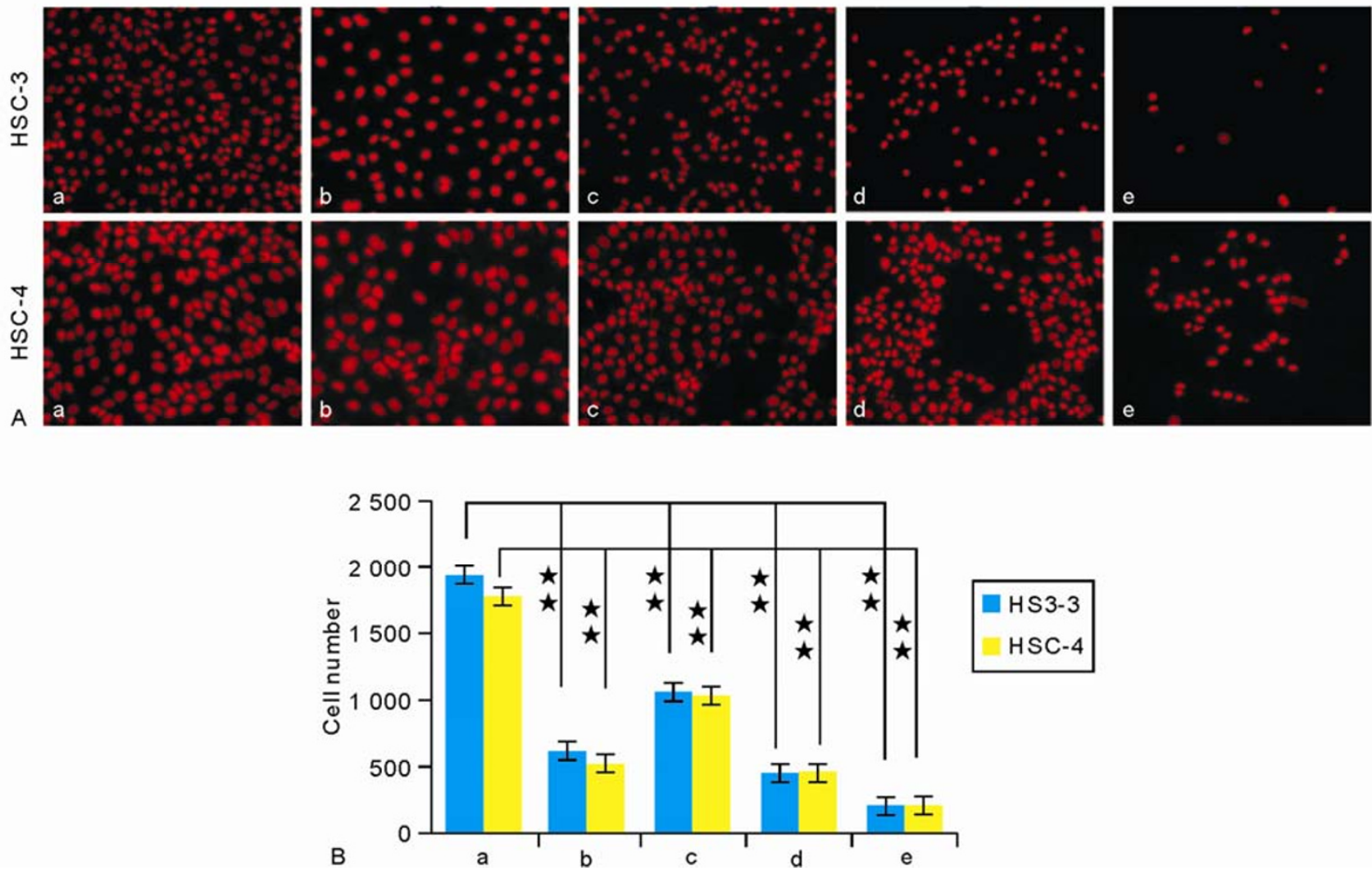

Figure 3 Inhibition of OSCC cells exposed to HNK or 5-Fu shown by PI assay. (A) HSC-3 or HSC-4 cells were treated as the described in Materials and Methods, and the inhibition effects of OSCC cells were measured by $\mathrm{PI}$ assay. $\times 100)$. (B) Quantitative analysis of the adherent cell numbers as shown as Figure A. The results indicated a significant decrease $(P<0.01)$ in cell number when the cells treated with $20 \mu \mathrm{g} \cdot \mathrm{mL}^{-1} 5$-Fu or three concentrations of $\mathrm{HNK}$ for $48 \mathrm{~h}$. And, the inhibition of OSCC cells increased remarkably $(P<0.01)$ when the concentration of HNK increased. The results were expressed as the mean \pm SD of the measurements $(n=5)$. Asterisk $(\star \star)$ indicated the significant value less than 0.01 . a: The control with drug treatments; b: 5-Fu; c-e: 10 , 15 or $20 \mu \mathrm{g} \cdot \mathrm{mL}^{-1} \mathrm{HNK}$, individually. 
The inhibitory power of HNK to OSCC cells also showed a dosage dependent manner

The inhibitory power of HNK to OSCC cells was measured by using the ratio of the cell number of OSCC cells between the treatment of different concentrations of HNK $\left(10,15\right.$, or $20 \mu \mathrm{g} \cdot \mathrm{mL}^{-1}$, respectively) for $48 \mathrm{~h}$ to 5 -Fu $\left(20 \mu \mathrm{g} \cdot \mathrm{mL}^{-1}\right)$ treatment for $48 \mathrm{~h}$ in both cell lines via MTT assays. As shown from the Table 1, the ratio of $\mathrm{HNK}\left(10 \mu \mathrm{g} \cdot \mathrm{mL}^{-1}\right)$ to 5 - $\mathrm{Fu}\left(20 \mu \mathrm{g} \cdot \mathrm{mL}^{-1}\right)$ was only around 0.5 . However, the value exceeded 1.5 fold at $15 \mu \mathrm{g} \cdot \mathrm{mL}^{-1}$, and reached 2.13-2.32 fold of $5-\mathrm{Fu}$ at the $20 \mu \mathrm{g} \cdot \mathrm{mL}^{-1}$ $\mathrm{HNK}$, indicating the inhibitory power of HNK to OSCC cells also had a dosage dependent manner.

To further confirm the above inhibitory power of HNK to OSCC cells, the ratio via PI assays of the number of OSCC cells between the treatment of different concentrations of $\mathrm{HNK}\left(10,15\right.$, or $20 \mu \mathrm{g} \cdot \mathrm{mL}^{-1}$, individually) for $48 \mathrm{~h}$ to $5-\mathrm{Fu}\left(20 \mu \mathrm{g} \cdot \mathrm{mL}^{-1}\right)$ treatment for $48 \mathrm{~h}$ in both cell lines were also counted. As listed in Table 2, the ratio of

the PI staining cells between HNK $\left(10 \mu \mathrm{g} \cdot \mathrm{mL}^{-1}\right)$ to 5 -Fu $\left(20 \mu \mathrm{g} \cdot \mathrm{mL}^{-1}\right)$ was also approximately 0.5 , and the value almost doubled to 1.05 to 1.12 at $15 \mu \mathrm{g} \cdot \mathrm{mL}^{-1} \mathrm{HNK}$ with a stable tendency around 1.29 to 1.31 at $20 \mu \mathrm{g} \cdot \mathrm{mL}^{-1}$ HNK. These results were consistent with the data from MTT, which confirmed the inhibitory power of HNK to OSCC cells.

HNK induced apoptosis in OSCC cells evidenced via morphological changes and DNA fragmentation detection

According to MTT results, we chose $15 \mu \mathrm{g} \cdot \mathrm{mL}^{-1}$ of HNK dosage group to further observe the possible changes in terms of morphology posterior to the treatment of HNK. Under the fluorescence reverse microscope, the HNK-treated cells clearly exhibited morphological features of apoptosis (Figure 4A) such as karyopyknosis, meniscus as well as cell shrinkage, etc. [19].
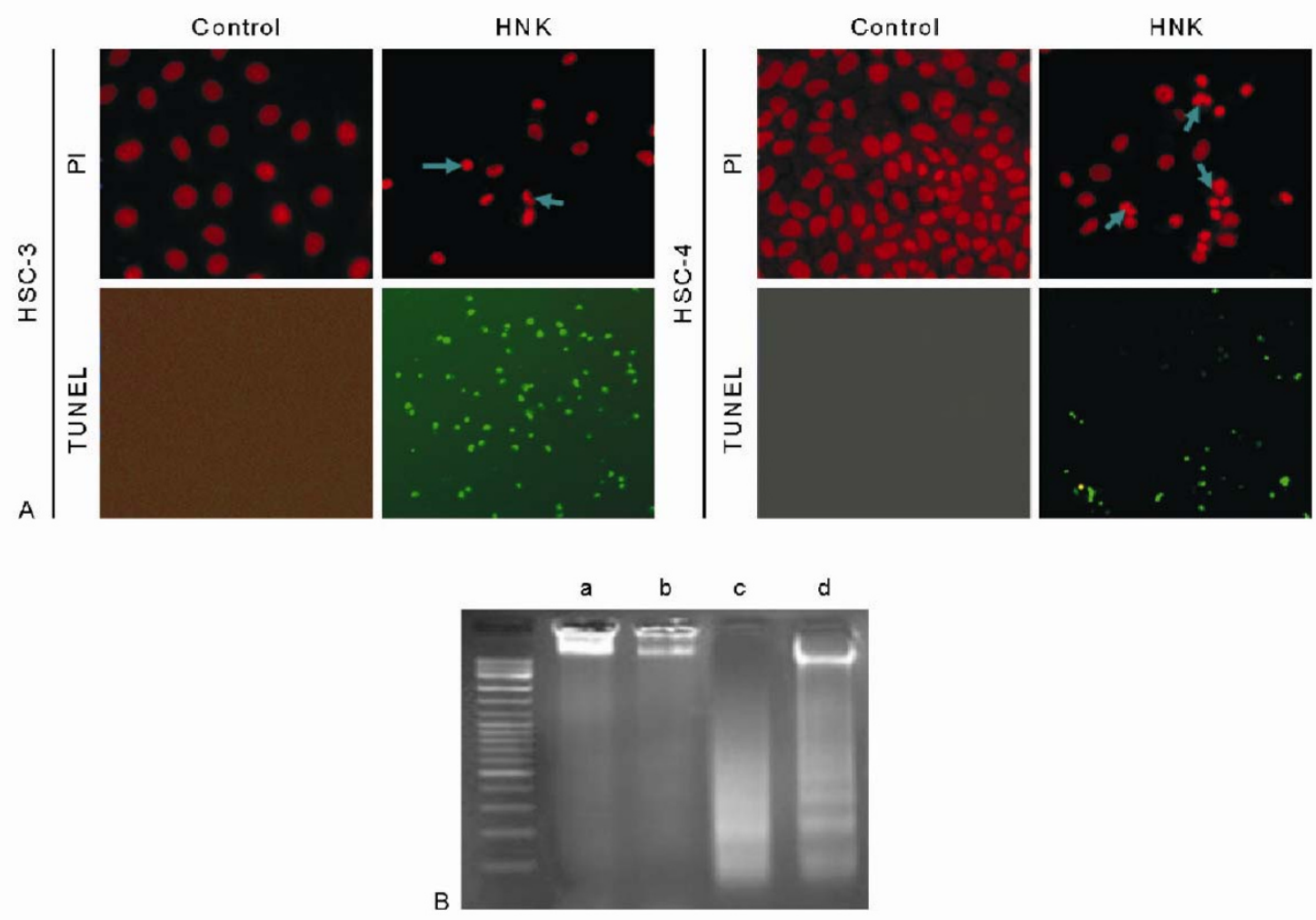

Figure 4 Morphological changes and DNA fragmentation in OSCC cells induced by HNK. HSC-3 and HSC-4 cells were exposed to $15 \mu \mathrm{g} \cdot \mathrm{mL}^{-1} \mathrm{HNK}$ for $48 \mathrm{~h}$ and then examined by three assays to detected the potential apoptotic effects, individually. (A) The examination of cell apoptosis by PI assay in HNK treated cells, exhibited morphological features of apoptosis: karyopyknosis, meniscus, cell shrinkage. Arrows indicate the apoptosis cells. $\times 200$. (B) Apoptotic effect was detected by TUNEL assay. $\times 100$. In HNK treated cells TUNEL-positive cells were presented. In HNK treated cells, a degradation of chromosomal DNA into small internucleosomal fragments was evidenced by the formation of 180-200 bp DNA ladders on agarose gels lane $c$ and d. Lane a and b: HSC-3 and HSC-4 blank control; Lane $c$ and d: HSC-3 and HSC-4 cells treated with $15 \mu \mathrm{g} \cdot \mathrm{mL}^{-1}$ of $\mathrm{HNK}$. 
Table 1 Ratio of the inhibition effects to OSCC cells between HNK to 5-Fu shown by MTT assay

\begin{tabular}{|c|c|c|c|c|c|c|}
\hline \multirow[t]{2}{*}{ Group } & \multicolumn{2}{|c|}{ HNK10 } & \multicolumn{2}{|c|}{ HNK15 } & \multicolumn{2}{|c|}{ HNK20 } \\
\hline & HSC-3 & HSC-4 & HSC-3 & HSC-4 & HSC-3 & HSC-4 \\
\hline HSC-3* & 0.58 & - & 1.65 & - & 2.32 & - \\
\hline HSC-4* & - & 0.5 & - & 1.54 & - & 2.13 \\
\hline
\end{tabular}

*The cells were treated with $20 \mu \mathrm{g} \cdot \mathrm{mL}^{-1} 5$-Fu.

Table 2 Ratio of the inhibition effects to OSCC cells between HNK to 5-Fu shown by PI assay

\begin{tabular}{|c|c|c|c|c|c|c|}
\hline \multirow[t]{2}{*}{ Group } & \multicolumn{2}{|c|}{ HNK10 } & \multicolumn{2}{|c|}{ HNK15 } & \multicolumn{2}{|c|}{ HNK20 } \\
\hline & HSC-3 & HSC-4 & HSC-3 & HSC-4 & HSC-3 & $\mathrm{HSC}-4$ \\
\hline HSC-3* & 0.64 & - & 1.12 & - & 1.29 & - \\
\hline HSC-4* & - & 0.58 & - & 1.05 & - & 1.31 \\
\hline
\end{tabular}

*The cells were treated with $20 \mu \mathrm{g} \cdot \mathrm{mL}^{-1} 5$-Fu.
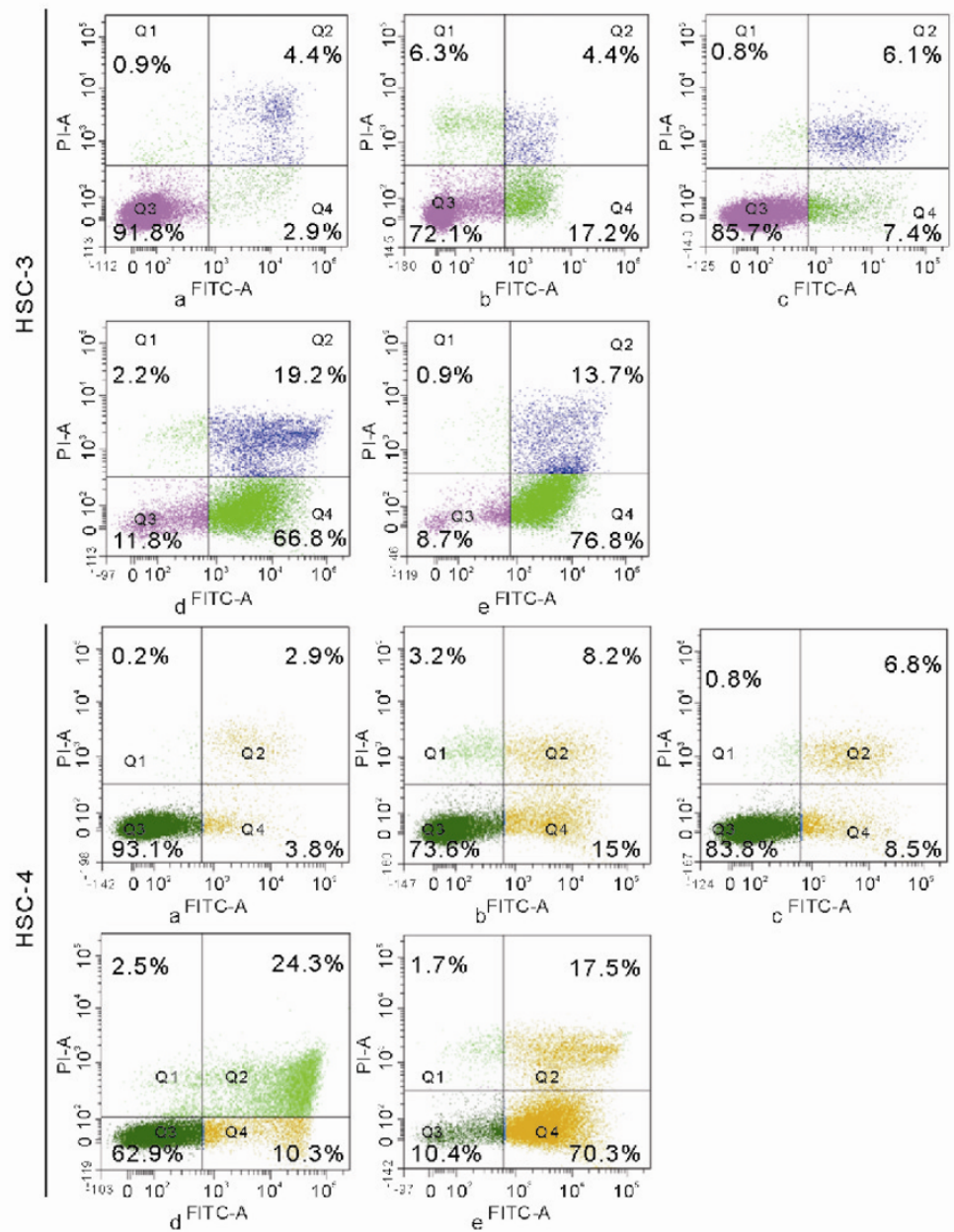

Figure 5 HNK induces apoptosis in OSCC cells exposed to HNK or 5-Fu shown by flow cytometry assay. HSC-3 or HSC-4 cells were treated as the described in Materials and Methods, and flow cytometry assay was used to analysis the apoptotic cells by Annexin-V FITC and PI double staining at $48 \mathrm{~h}$ posterior to the treatment. Lower left quadrant, viable cells; lower right quadrant (AV-positive but PI-negative cells), early apoptosis cells; upper left quadrants, necrotic cells; upper right quadrant, late apoptosis cells. The results indicated that HNK induced an apoptotic cell death in a dose-dependent manner in both HSC-3 and HSC-4 cells. And, the apoptotic cells proportion treated with HNK (15 or $20 \mu \mathrm{g} \cdot \mathrm{mL}^{-1}$ ) were $1.49-4.19$ fold higher than that of $20 \mu \mathrm{g} \cdot \mathrm{mL}^{-1} 5-\mathrm{Fu}$ group. a: The control with drug treatments; b: 5-Fu; c-e: 10,15 or $20 \mu \mathrm{g} \cdot \mathrm{mL}^{-1} \mathrm{HNK}$, individually. 
A more sensitive assay, fluorescence TUNEL system, was also conducted to detect the DNA strand breaks by labeling free 3'-OH termini. In HNK treated cells, TUNELpositive cells were presented (Figure 4A). A degradation of chromosomal DNA into small internucleosomal fragments was remarkably evidenced by the formation of 180-200 bp DNA ladders on agarose gels (Figure 4B), the hallmark of cells undergoing apoptosis. Meanwhile, no DNA ladders were observed in the control cultures (Figure 4B).

These results strongly suggested that HNK induced an apoptotic cell death in OSCC cells.

HNK induced apoptosis in OSCC cells, evidenced by flow cytometry assays

To further confirm that the inhibition of HNK on the growth of OSCC cells was caused by apoptosis, the percentage of apoptotic cells in $\mathrm{HNK}$ - or 5-Fu-treated OSCC cells was evaluated by the flow cytometry assay after the double staining of Annexin- $\mathrm{V}$ fluorescein isothiocyanate (FITC) and propidium iodide (PI). The ratio of apoptotic cells increased in both of the OSCC cell lines with the increase of the concentration of $\mathrm{HNK}$ as compared with the blank control (Figure 5). Furthermore, the ratio of the apoptotic cell proportion (early apoptosis cells and late apoptosis cells, Table 3 ) of cells between $\mathrm{HNK}\left(10 \mu \mathrm{g} \cdot \mathrm{mL}^{-1}\right)$ to $5-\mathrm{Fu}\left(20 \mu \mathrm{g} \cdot \mathrm{mL}^{-1}\right)$ was near 0.6 , and the value grown up to 3.98 (HSC-3) and 1.49 (HSC-4) at $15 \mu \mathrm{g} \cdot \mathrm{mL}^{-1}$ treatment, respectively, with a relative stable at 4.19 (HSC-3) or 3.78 (HSC-4) at $20 \mu \mathrm{g} \cdot \mathrm{mL}^{-1} \mathrm{HNK}$, concurring with the inhibitory power of HNK to OSCC assessed by the ratio of MTT or PI assay.

Table 3 Ratio of the apoptotic cells proportion of cells between HNK to 5-Fu shown by flow cytometry analysis

\begin{tabular}{|c|c|c|c|c|c|c|}
\hline \multirow[t]{2}{*}{ Group } & \multicolumn{2}{|c|}{ HNK10 } & \multicolumn{2}{|c|}{ HNK15 } & \multicolumn{2}{|c|}{ HNK20 } \\
\hline & HSC-3 & HSC-4 & HSC-3 & HSC-4 & HSC-3 & HSC-4 \\
\hline HSC $-3 *$ & 0.63 & - & 3.98 & - & 4.19 & - \\
\hline HSC-4* & - & 0.65 & - & 1.49 & - & 3.78 \\
\hline
\end{tabular}

*The cells were treated with $20 \mu \mathrm{g} \cdot \mathrm{mL}^{-1} 5-\mathrm{Fu}$.

\section{Discussion}

Oral squamous cell carcinoma (OSCC) is one of the most common malignancies that remain incurable with current therapies. As a particular type of head and neck squamous cell carcinoma, OSCC patients have been commonly treated with cisplatin (or carboplatin) and/or 5-Fu, traditionally [20]. However, drug resistance often recurs, accompanied by distressing symptoms [21]. The response rate to most commonly used cytotoxic agents was only about $30 \%-40 \%$ in large studies [22]. Previous studies have demonstrated that the acquired drug resistance of cancer cells was associated with the alterations in apoptosis [23]. In other words, drug resistance to currently used chemotherapeutics was proposed to be partly mediated by the ability of the tumor cells to circumvent apoptosis [24-26]. Therefore, the inhibition of apoptosis is taken as a major contributing factor to drug-resistance in cancer cells. From this point of view, new treatment approaches with different mechanisms of apoptosis induction are all urgently being explored to overcome the limited effectiveness of current treatment modalities for OSCC. It appears that exploiting the apoptotic potential of OSCC would lead to contemporary therapies that might be less toxic to normal cells due to their physiologically-controlled survival pathways.
$\mathrm{HNK}$, a natural product isolated from magnolia grandiflora, has multiple pharmacologic actions including antioxidative, anti-angiogenesis, and antitumor effects and so on [6-7, 10, 17, 27]. Previous studies suggest that growth inhibition by $\mathrm{HNK}$ resulted from the induction of apoptosis in several cell lines [9-10, 27-29]. A further study reported that HNK induces a necrotic cell death through the mitochondrial permeability transition pore [30]. Moreover, it is known for its low toxicity in normal peripheral blood mononuclear cell (PBMNC) or primary cultured human cells [17, 31-33]. However, little evidence is available for its effects on OSCC cells.

We have first tested the effects of HNK on oral squamous cell carcinoma cell models in the current study by MTT and PI assays to explore the inhibition potential of HNK on OSCC cells growth and proliferation. We have found that $\mathrm{HNK}$ inhibits the growth and proliferation of OSCC cells with a dosage- and time-dependent manner, which is consistent with the previous reports in other cells [17].

Furthermore, we have proposed the inhibitory power as a novel index by using the ratio of the cell number or the inhibitory effects of OSCC cells between the treatment of $\mathrm{HNK}$ to 5-Fu (positive group) treatment via MTT assays, PI assays, FCM assays to further illustrate the ability of HNK on OSCC cells for the first time. 
From this novel index, we have further confirmed and enhanced the preliminary results that HNK inhibits the growth and proliferation of OSCC cells in a dosage- and time-dependent manner, which have obtained solely via MTT, PI, or FCM assays. In fact, this novel strategy could be used for the assessment of the inhibitory effects of any new drug that have potential to be candidate reagents for the treatment of oral squamous carcinoma or other tumors compared with conventional ones such as 5-Fu or cisplatin.

Moreover, we have found that HNK induced apoptosis in vitro in OSCC cells, evidenced by PI assay, TUNEL assay, DNA ladder assay, and FCM assay, suggesting the HNK may be a novel treatment agent to overcome drug-resistance in OSCC cancer cells, although more studies in vivo will be warranted.

On the other hand, some of previous studies have explored two modes of mechanisms in which HNK takes to induce the apoptosis or necrosis in the other cancer cell models [8-13, 17, 27, 33-34]. In brief, HNK have demonstrated the potentiating to activate the extrinsic pathways of cell apoptosis in tumors with p53 depletion or mutation (i.e. the activation of caspase 3,7 , and 9 have been noted). At the same time, the alternative (intrinsic) pathway (associated with mitochondrial dysfunction, reactive oxygen generation, and necrosis) may be more important in tumors with wild-type p53. Whether HNK takes the same mechanisms or any other novel pathways to make its antitumor activity in OSCC is currently under further studies via in vitro and in vivo experiments in our group.

In summary, our study has demonstrated that growth inhibition by $\mathrm{HNK}$ resulted from the induction of apoptosis in OSCC cell lines in vitro. Our findings suggest that HNK may be a promising agent that can be further studied as a novel treatment agent for human OSCC.

\section{Acknowledgements}

This work was supported by grants from the National Science Funds for Talented Professionals of China (No. 30725041), the National Natural Science Foundation of China (No. 30930100, 30672323, 81072218), State Key Laboratory of Oral Diseases Open Funding (SKLODOF 2010-01) of China, and the Changjiang Professorship Support Program of Ministry of Education, China.

\section{References}

1 Garcia M, Jemal A, Ward EM, et al. Global cancer facts \& figures 2007. on World Wide Web http://www.cancer.org/acs/ groups/content/@nho/documents/document/globalfactsandfig ures2007rev2p.pdf. [accessed on 26/10/2010].

2 Qiu WL, Zheng JW. Development of oral maxillofacial oncology in China. Chin Med J (Engl) 2003; 116: 1567 1573.

3 Wingo PA, Tong T, Bolden S. Cancer statistics, 1995. CA Cancer J Clin 1995; 45: 8-30.

4 Liou KT, Lin SM, Huang SS, Chih CL, Tsai SK. Honokiol ameliorates cerebral infarction from ischemia-reperfusion injury in rats. Planta Med 2003; 69: 130-134.

5 Teng CM, Chen CC, Ko FN, et al. Two antiplatelet agents from Magnolia officinalis. Thromb Res 1988; 50: 757-765.

6 Lo YC, Teng CM, Chen CF, Chen CC, Hong CY. Magnolol and honokiol isolated from magnolia officinalis protect rat heart mitochondria against lipid peroxidation. Biochem Pharmacol 1994; 47: 549-553.

7 Kuribara H, Kishi E, Hattori N, Yuzurihara M, Maruyama Y. Application of the elevated plus-maze test in mice for evaluation of the content of honokiol in water extracts of magnolia. Phytother Res 1999; 13: 593-596.

8 Hirano T, Gotoh M, Oka K. Natural flavonoids and lignans are potent cytostatic agents against human leukemic HL-60 cells. Life Sci 1994; 55: 1061-1069.

9 Yang SE, Hsieh MT, Tsai TH, Hsu SL. Down-modulation of Bcl-XL, release of cytochrome $\mathrm{c}$ and sequential activation of caspases during honokiol-induced apoptosis in human squamous lung cancer CH27 cells. Biochem Pharmacol 2002; 63: 1641-1651.

10 Bai X, Cerimele F, Ushio-Fukai M, et al. Honokiol, a small molecular weight natural product, inhibits angiogenesis in vitro and tumor growth in vivo. $J$ Biol Chem 2003; 278: 35501-35507.

11 Zhai H, Nakade K, Mitsumoto Y, Fukuyama Y. Honokiol and magnolol induce $\mathrm{Ca}^{2+}$ mobilization in rat cortical neurons and human neuroblastoma SH-SY5Y cells. Eur J Pharmacol 2003; 474: 199-204.

12 Park EJ, Zhao YZ, Kim YH, Lee BH, Sohn DH. Honokiol induces apoptosis via cytochrome c release and caspase activation in activated rat hepatic stellate cells in vitro. Planta Med 2005; 71: 82-84.

13 Hahm ER, Singh SV. Honokiol causes G0-G1 phase cell cycle arrest in human prostate cancer cells in association with suppression of retinoblastomaretino-blastoma protein level/phosphorylation and inhibition of E2F1 transcriptional activity. Mol Cancer Ther 2007; 6: 2686- 2695.

14 Feng Y, He F, Zhang P, et al. Inhibitory effect of HMGN2 protein on human hepatitis $\mathrm{B}$ virus expression and replication in the HepG2.2.15 cell line. Antiviral Res 2009; 81: 277-282.

15 Luo H, Zhong Q, Chen LJ, et al. Liposomal honokiol, a promising agent for treatment of cisplatin-resistant human ovarian cancer. J Cancer Res Clin Oncol 2008; 134: 937 945. 
16 Shen J, Huang C, Jiang L, et al. Enhancement of cisplatin induced apoptosis by suberoylanilide hydroxamic acid in human oral squamous cell carcinoma cell lines. Biochem Pharmacol 2007; 73: 1901-1909.

17 Wang T, Chen F, Chen Z, et al. Honokiol induces apoptosis through p53-independent pathway in human colorectal cell line RKO. World J Gastroenterol 2004; 10: 2205-2208.

18 Lockshin RA, Zakeri Z. Programmed cell death and apoptosis: origins of the theory. Nat Rev Mol Cell Biol 2001; 2: 545550 .

19 Wang Z, Jiang L, Huang C, et al. Comparative proteomics approach to screening of potential diagnostic and therapeutic targets for oral squamous cell carcinoma. Mol Cell Proteomics 2008; 7: 1639-1650.

20 Go RS, Adjei AA. Review of the comparative pharmacology and clinical activity of cisplatin and carboplatin. J Clin Oncol 1999; 17: 409-422.

21 Khuri FR, Shin DM, Glisson BS, Lippman SM, Hong WK. Treatment of patients with recurrent or metastatic squamous cell carcinoma of the head and neck: current status and future directions. Semin Oncol 2000; 27: 25-33.

22 Forastiere AA, Metch B, Schuller DE, et al. Randomized comparison of cisplatin plus 5-Fu and carboplatin plus 5-Fu versus methotrexate in advanced squamous-cell carcinoma of the head and neck - a Southwest-oncology-group study. $J$ Clin Oncol 1992; 10: 1245-1251.

23 Kaufmann SH, Vaux DL. Alterations in the apoptotic machinery and their potential role in anticancer drug resistance. Oncogene 2003; 22: 7414-7430.

24 Ferreira CG, Epping M, Kruyt FA, Giaccone G. Apoptosis: target of cancer therapy. Clin Cancer Res 2002; 8: 2024 2034.
25 Malaguarnera L. Implications of apoptosis regulators in tumorigenesis. Cancer Metastasis Rev 2004; 23: 367-387.

26 Luqmani YA. Drug resistance in cancer chemotherapy. Med Princ Pract 2005; 14: 35-48.

27 Chen F, Wang T, Wu YF, et al. Honokiol: a potent chemotherapy candidate for human colorectal carcinoma. World $J$ Gastroenterol 2004; 10: 3459-3463.

28 Hibasami H, Achiwa Y, Katsuzaki H, et al. Honokiol induces apoptosis in human lymphoid leukemia Molt 4B cells. Int J Mol Med 1998; 2: 671-673.

29 Nagase H, Ikeda K, Sakai Y. Inhibitory effect of magnolol and honokiol from Magnolia obovata on human fibrosarcoma HT-1080. Invasiveness in vitro. Planta Med 2001; 67: 705-708.

30 Li L, Han W, Gu Y, et al. Honokiol induces a necrotic cell death through the mitochondrial permeability transition pore. Cancer Res 2007; 67: 4894-4903.

31 Tsai SK, Huang SS, and Hong CY. Myocardial protective effect of honokiol: an active component in magnolia officinalis. Planta Med 1996; 62: 503-506.

32 Chiu JH, Ho CT, Wei YH, Lui WY, Hong CY. In vitro and in vivo protective effect of honokiol on rat liver from peroxidative injury. Life Sci 1997; 61: 1961-1971.

33 Ishitsuka K, Hideshima T, Hamasaki M, et al. Honokiol overcomes conventional drug resistance in human multiplemyeloma by induction of caspase-dependent and -independent apoptosis. Blood 2005; 106: 1794-1800.

34 Garcia A, Zheng Y, Zhao C, et al. Honokiol suppresses survival signals mediated by Ras-dependent phospholipase D activity in human cancer cells. Clin Cancer Res 2008; 14: $4267-4274$ 